The University of Akron

\title{
IdeaExchange@UAkron
}

Proceedings from the Document Academy

University of Akron Press Managed

December 2018

\section{The Public Library and Social Media: A Case Study from Tromsø, Norway}

Roswitha Skare

University of Tromso, roswitha.skare@uit.no

Please take a moment to share how this work helps you through this survey. Your feedback will be important as we plan further development of our repository.

Follow this and additional works at: https://ideaexchange.uakron.edu/docam

Part of the Library and Information Science Commons

\section{Recommended Citation}

Skare, Roswitha (2018) "The Public Library and Social Media: A Case Study from Tromsø, Norway," Proceedings from the Document Academy: Vol. 5 : Iss. 2 , Article 11.

DOI: https://doi.org/10.35492/docam/5/2/11

Available at: https://ideaexchange.uakron.edu/docam/vol5/iss2/11

This Conference Proceeding is brought to you for free and open access by University of Akron Press Managed at IdeaExchange@UAkron, the institutional repository of The University of Akron in Akron, Ohio, USA. It has been accepted for inclusion in Proceedings from the Document Academy by an authorized administrator of

IdeaExchange@UAkron.For more information, please contact mjon@uakron.edu, uapress@uakron.edu. 


\section{Introduction}

Historically, archives, libraries and museums (ALM) have been perceived as institutions providing infrastructure for an open and enlightened public discourse. The Norwegian Public Libraries Act (Lov om folkebibliotek), ${ }^{1}$ for instance, focuses on public libraries being providers of knowledge and cultural expressions, agents of popular enlightenment, local meeting places and arenas of debate and participation in the public sphere.

At the same time as the public libraries' function as physical meeting places and arenas for public debate is highlighted in government policies, the public libraries are also supposed to keep up with the technological development and to offer digital services to the inhabitants of their municipality. Digital literacy, digital divide, digital inclusion but also self-service libraries and the consequences of digitization for making the libraries collections available for the users are topics discussed in the literature (e.g., Engström \& Eckerdal, 2017; Real, McDermott, Bertot \& Jaeger, 2015; Yerbury \& Henninger, 2018). But public libraries do not only have official webpages offering their patrons information and self-service; they are also present on social media platforms like Facebook, Twitter, Instagram and YouTube. ${ }^{2}$

Discussions about the Internet and especially about Web 2.0 and social media platforms often stress their democratic potential, as they provide meeting places where user contribution, collective intelligence, reuse and remix (Jenkins, 2006). Also, empowerment and ownership have become buzzwords since the mid2000s. Participation in terms of individuals becoming "creators and primary subjects" who communicate "effectively into the public sphere" (Benkler, 2006, p. 213 ) is discussed as the Internet's democratizing potential leading to the emergence of a network public sphere (Benkler, 2006, p. 272).

As pointed out by Carlsson, "The body of academic research studying the use of social web in public libraries" (Carlsson, 2015, p. 632) is growing. Nevertheless, "empirical work that explores the consequences of social web for public libraries in situ" (Carlsson, 2015, p. 644) is missing. Furthermore, there are almost no discussions about public libraries' presence on social media and whether, for instance, a Facebook page functions as a digital meeting place or not.

\footnotetext{
${ }^{1}$ See https://lovdata.no/dokument/NL/lov/1985-12-20-108

296 percent of the Norwegian population (aged 16-79) have used the Internet during the last three months, as of September 2018, according to Statistics Norway www.ssb.no/en/teknologi-oginnovasjon/statistikker/ikthus
} 


\subsection{Aim and Research Questions}

This paper presents the first findings of an ongoing research project ${ }^{3}$ investigating the relationship between physical meetings at the Tromsø Public Library and posts at the library's Facebook page. What kind of user participation do these two places create? Who participates and in what way? What are the questions discussed? What differences can be observed between the different arenas?

\section{Tromsø Public Library, User Behavior, and Social Media Presence}

\subsection{Tromsø Public Library}

Tromsø Public Library serves a municipality with almost 75.000 inhabitants. The numbers reported for last year (2017) show that the library had 7.8 visits and 4.7 loans total per inhabitant. While the last number is slightly higher than the average number for Norway as a whole, the number of visits is almost doubled compared to the average number for Norway. In 2017, the library hosted 727 events with a total of 17.292 participants. This makes about 23 persons per event, a slightly lower number than the average number for all events in Norway that year. ${ }^{4}$

In addition to these numbers from 2017, we also have the findings from a study conducted in 2015. ${ }^{5}$ This study investigated the user behavior at public libraries in Norway's larger cities Bergen, Kristiansand, Oslo, Stavanger, Trondheim, and Tromsø. Tromsø was included for the first time. The methodological approach was, as in earlier similar studies, observation.

According to this study, Tromsø Public Library has:

- users with the longest average visit time (about 70 minutes)

- the lowest proportion of traditional library users: $29 \%$ are borrowing or delivering materials, while $14 \%$ are looking at the materials in the shelves or at exhibited materials

- $8 \%$ of the visitors are at the library without using the services

- the proportion of children under 15 years is highest in Tromsø with $8 \%$

- the proportion of men is lowest in Tromsø with only $35 \%$, while women represent $65 \%$ of the users

\footnotetext{
${ }^{3}$ This research is funded by the Research Council of Norway and part of a three-year research project with the title "The ALM-Field, Digitalization, and the Public Sphere (ALMPUB)." See https://almpub.wordpress.com for more information

${ }^{4}$ These numbers are according to the statistics made available by the National Library of Norway (only in Norwegian). See https://bibliotekutvikling.no/statistikk/statistikk-for-norskebibliotek/folkebibliotek/

5 The complete study (only in Norwegian) can be downloaded at https://bergenbibliotek.no/aktuelt/hvem-er-de-og-hva-gjor-de
} 
- $33 \%$ of the users are visiting the library together with others, they meet friends at the library or using the services together with others

- $3 \%$ are visiting the area with computers

- $1 \%$ is attending events at the library or is taking part in any kind of training The report says nothing about the libraries' use of social media and the activity that takes place there.

\subsection{Tromsø Public Library’s Digital Services and Social Media Presence}

Tromsø Public Library has an official web page with self-service opportunities for patrons like searching the library database or managing loans, information about opening hours, current events, and contact information. Here we also find links to social media platforms the library is present at: Facebook, Flickr, Twitter, YouTube, and Instagram.

I will in the following concentrate on the library's Facebook page because, first, Facebook is by far the most popular social media platform with about $64 \%$ of the Norwegian population having a Facebook account in 2017. As of June 26, 2018, 3,940 persons like the Facebook page of the Tromsø Public Library, while 1,256 follow the library on Instagram, 674 on Twitter, and 17 on Flickr. Second, about the same content is shared on all

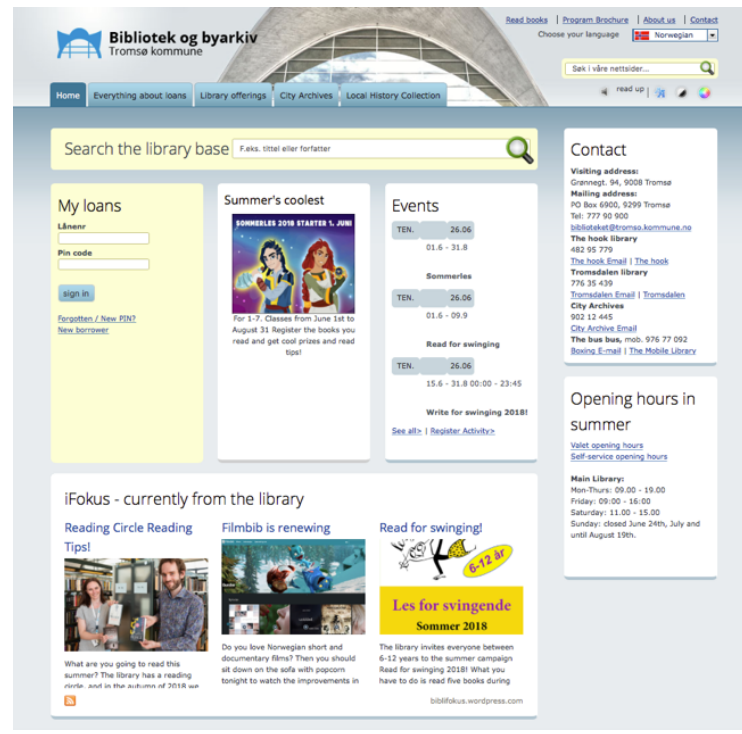

Screenshot of the library's web page on June 26, 2018 the different platforms, Facebook is the one platform combining text, images and videos. At the same time Facebook gives the user the possibility to like, share and comment, both communicating with the library and with other users.

The period analyzed are the first six months of 2018, from January 1 until June 30. Even though the time period studied is limited, the results indicate some interesting tendencies (see Table 1).

In the first six months of the year, 133 posts were made, with a pretty constant monthly distribution. The only month with fewer posts than average is May, a month with many holidays in Norway. A large part of the posts are event announcements and shared content. Posts about literature, either book reviews or suggestions for what to read, are - not surprisingly for a library - frequent. Only a few posts are formulated as questions to the patrons or as an invitation to contribute, for instance by sending in a photo of one's bookshelf or asking children to make a drawing for the library. Only two of the posts ask for opinions about literature. 
Table 1. Facebook posts in the first six months of 2018

$\begin{array}{cccccccc}\begin{array}{c}\text { Total } \\ \text { posts }\end{array} & \begin{array}{c}\text { Book revs, } \\ \text { literature6 }\end{array} & \text { Event } & \begin{array}{c}\text { Shared } \\ \text { content }\end{array} & \text { Questions } & \text { Info }^{7} & \begin{array}{c}\text { At the } \\ \text { library }\end{array} & \text { Other } \\ 21 & 1 & 10 & 7 & 19 & & 2 & \\ 25 & 5 & 11 & 6 & & 5 & 2 \\ 24 & 4 & 6 & 5 & 2 & 3 & 3 \\ 24 & 4 & 9 & 5 & & 4 & \\ 17 & 3 & 5 & 4 & 1 & 8 & 1\end{array}$

Most of the posts -85 out of 133 in total-have between 0 and 10 likes. Taking into consideration that almost 4000 people like the page and are engaged in one way or another in the content of the page, this number suggests little user engagement. Only a few posts create more activity, nevertheless the activity is limited to likes or sharing. There are almost no comments. A closer look at the three posts with the most likes ${ }^{11}$ illustrate this:

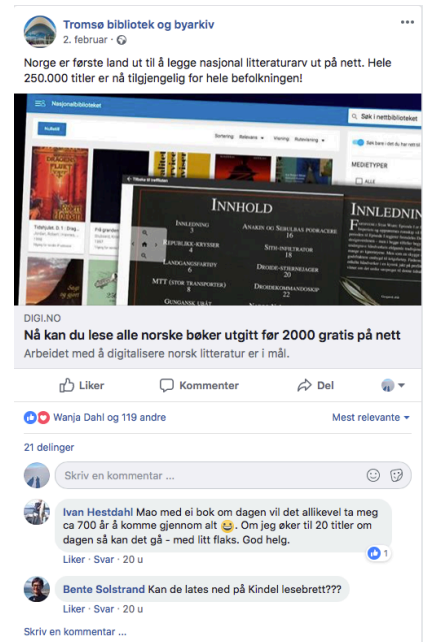

120 likes, 21 shares, 2 comments

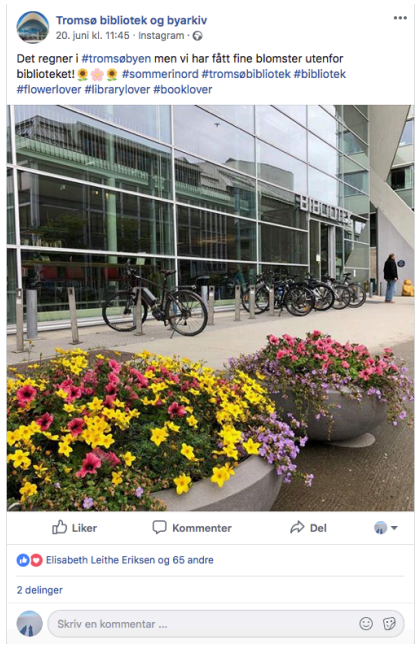

66 likes, 2 shares, no comments

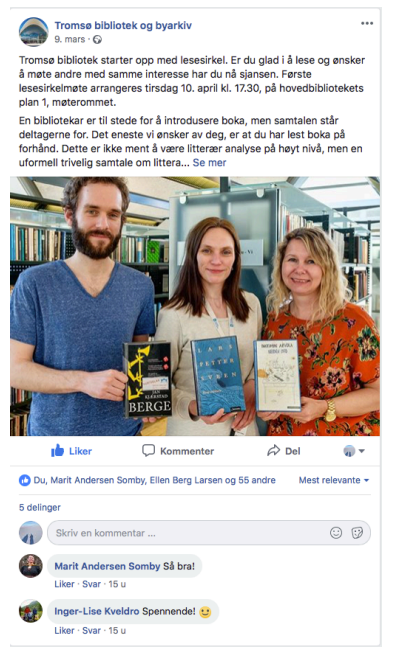

58 likes, 5 shares, 2 comments

${ }^{6}$ For instance, about the death of an author or the nomination of an author for a prize

${ }^{7}$ Practical information about opening hours or problems at the library, but also about positions at the library

${ }^{8}$ Pictures from events, but also pictures showing how it looks like at the library right now

${ }^{9}$ Shared link from British newspaper about Virginia Woolf but combined with a question to the patrons

${ }^{10}$ Sámi national day

${ }^{11}$ Screenshots from June 26, 2018 
The content in 2 of these 3 posts is about literature and about activities planned at the library. One of the posts is about the summer weather in Tromsø. Even if these posts get some comments, there is no conversation between the persons involved or between the library and its users.

Even if six months is a limited time period, this analysis confirms Ahorany's observations from 2012 that libraries are using their Facebook pages "simply as a way to deliver information to users, rather than as a venue for discussion" (Aharony, 2012, p. 366). Other case studies confirm the finding that ALM institutions employ social media platforms like Facebook "as one-way instruments of promotion and publicity" (Lazzaretti et al, 2015, p. 269). In a study consisting of 99 Portuguese public libraries with a Facebook page, the authors were looking for "actions with facets of the social mission" (Alvim \& Calixto, 2016, p. 165). The authors conclude that the libraries "rarely publish social character actions" (Alvim $\&$ Calixto, 2016, p. 174) even if they consider the promotion of events as an act of social inclusion (Alvim \& Calixto, 2016, p. 168). ${ }^{12}$

It is striking that in posts where the library asks questions and tries to get a response from its users (only four during these six months), that these posts are not creating much response or any kind of conversation. It seems like users are engaged in activities that demand little commitment like liking and sharing of posts. From outside it is impossible to know how many users actually read the library's posts, and whether they are engaged by the content or not. Since most of the posts are information to the public that do not demand any kind of reaction or engagement, we might assume that people following the library are not used to much activity in form of discussions on that Facebook page. There are also different reasons for following the library on Facebook and one group of people might be individuals who are using the library on a regular basis and have a positive attitude to the library and its activities or have a professional interest in following the library.

The Facebook page of the Tromsø Public Library functions in a very limited way as a digital meeting place, we might conclude. The possibilities to comment and to get into a conversation with other patrons or the library itself are not used.

\section{Live Events at the Public Library}

To compare these findings with observations from the physical library, I attended two events in September 2018. The first one was a meeting of the reading group, discussing the novel Berge by the Norwegian author Jan Kjærstad on September 4. The day after, the author visited the library to have a talk about the novel. The novel had great success when it first came out in 2017, engaging its readers by its being a crime story about the murder of a Norwegian Labor Party minister and several

12 The authors observed pages of 99 public libraries on Facebook "in the second half of July 2014 and focused in the months of May to July" (Alvim \& Calixto, 2016, p. 167). They found 327 posts during these 76 days, an average of only three posts per library. 
members of his family in 2008. According to the author, "Berge is a story of horrible events, told from three different points of view. A journalist, a judge and an ex-boyfriend. Without touching on the July 22 attack in Norway, Berge is a novel that would not have been written without it." 13

Even if the results of these observations are very limited and have to be followed up by more observing, there is an interesting tendency: 11 women participated in the reading group, 9 out of these 11 probably older than $50 .{ }^{14}$ The reading group was organized in a room at the library with everybody sitting around a table. The atmosphere was friendly and relaxed. There was only a short introduction with first name and first reading impressions. I therefore have no information about the participant's occupation or education level. All did participate in the conversation about the novel, even if 2 or 3 were more active than the other. Topics discussed were the murder riddle, the author's style of writing and the like, but also about Norway, the Norwegian society and what it means to be Norwegian. Questions related to Norwegian society were probably caused by the topic and the obvious relation to the July $22^{\text {nd }}$ attack. After 90 minutes the reading group was ended by the librarian responsible for the event, not because the group had found all the answers or had nothing more to discuss, but because time was up.

About 80 persons came to the event the day after when the author visited the library. Again, women were the clear majority, but also about 15-20 men attended. The age did vary more than in the reading group with more young people, probably students, being part of the audience. 8 out of the 11 women from the reading group were also present. Only one of these asked the author a question. Several other participants asked a question when encouraged to do so. Compared to the conversation the day before, these questions asked by the audience did not lead to a conversation among the audience but only to an answer from the author.

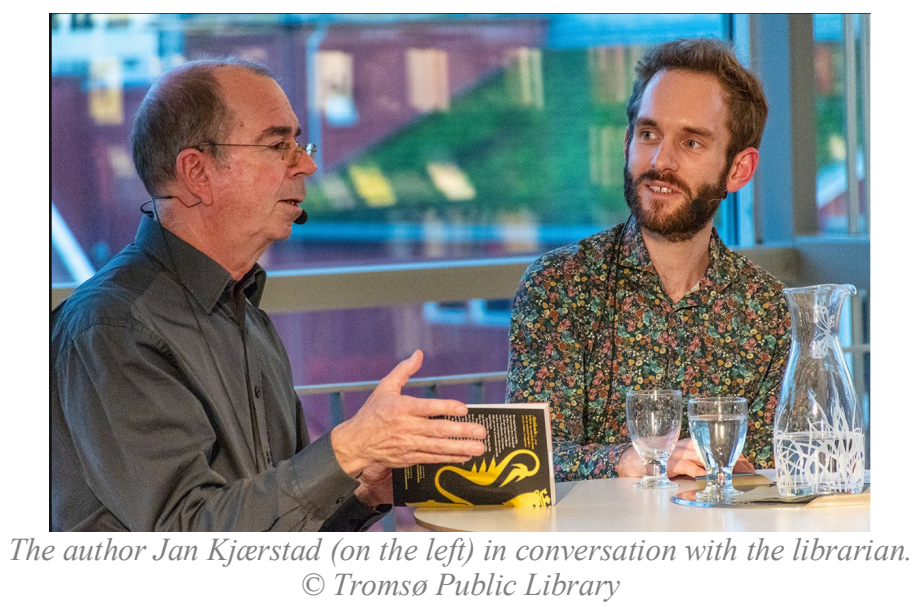

13 http://www.jankjaerstad.no/berge.php

14 Another reading group was arranged on October 2, 2018. Eleven women (only 3-4 were the same as last time) and one man attended. Again, the conversation was lively, and everyone contributed. 
These findings are not surprising: The fewer persons attending the reading group can be explained by the requirement to have read the novel and to take part actively in a conversation about the book. The low number of participants probably makes it easier for the participants to feel comfortable to speak to each other. The author's presence the next day might have contributed to attract more people to visit the event because of his reputation in Norway. In addition to that, the meeting with the author is less compulsive and the threshold to participate much lower. There are no expectations to the audience except listening to a conversation being one of many in an audience. This might explain the high number of participants.

Last but not least, these two events created small public spheres different from each other but with a common topic and with some participants being part of both spheres. Further observations are needed to characterize the public spheres created by different events in more detail. I will also interview the participants and librarians about their expectations and use of the library and its Facebook page.

\section{References}

Aharony, N. (2012). Facebook use in libraries: An exploratory analysis. Aslib Proceedings, 64(4), 358-372.

Alvim, L., \& Calixto, J. A. (2016). Content analysis model to analyze facets of social mission of public library on the Facebook and in the websites. Qualitative \& Quantitative Methods in Libraries, 5, 165-176.

Benkler, Y. (2006). The wealth of networks. New Haven: Yale University Press.

Carlsson, H. (2015). Researching public libraries and the social web, 20062012. Journal of Documentation, 71(4), 632-649.

Engström, L., \& Eckerdal, J. R. (2017). In-between strengthened accessibility and economic demands: Analysing self-service libraries from a user perspective. Journal of Documentation, 73(1), 145-159.

Jenkins, H. (2006), Convergence culture: Where old and new media collide. New York: New York University Press.

Lazzeretti, L., Sartori, A., \& Innocenti, N. (2015). Museums and social media: The case of the Museum of Natural History of Florence. International Review of Public Nonprofit Marketing, 12, 267-283.

Papacharissi, Z. (2009). The virtual sphere 2.0: The internet, the public sphere, and beyond. In A. Chadwick \& P. N. Howawd (Eds.), Routledge handbook of internet politics (pp. 230-245). New York: Routledge.

Real, B., McDermott, A., Bertot, J. C., \& Jaeger, P. T. (2015). Digital inclusion and the Affordable Care Act: Public libraries, politics, policy, and enrollment in "Obamacare." Public Library Quarterly, 34(1), 1-22.

Yerbury H., \& Henninger M. (2018). Civil commitment and the role of public librarians. In S. Kurbanoğlu, J. Boustany, S. Špiranec, E. Grassian, D. Mizrachi, \& L. Roy (Eds.), Information literacy in the workplace: ECIL 2017 (pp. 376-385). Cham, Switzerland: Springer. 